\title{
Role of circulating immune complexes in renal diseases
}

\author{
ROLAND J LEVINSKY
}

From the Department of Immunology, Institute of Child Health, 30 Guilford Street, London WCI

The elimination of a foreign antigen is a function of the antibody, complement and phagocyte systems. When an immune complex is formed in the circulation, clearance is effected by cells of the reticuloendothelial system. Macrophages and polymorphonuclear cells have both IgG Fc and C3b complement receptors so that opsonisation by either the classical or the alternative pathway of complement activation facilitates antigen elimination. This system normally provides a most efficient protection against disease, since man is continually challenged by a variety of inhaled and ingested antigens.

Why then does a normally protective system become self-damaging, resulting in immune complex disease? It is unlikely that most immune complex diseases are due to rare or as yet unidentified antigens. It is much more likely that host variation in immune response to a common antigen resuits in effective clearance and health in one individual, but persistent circulating antigen and immune complex disease in another. Increased concentrations of circulating soluble immune complexes are found in a variety of diseases; these include systemic lupus erythematosus, various forms of glomerulonephritis, rheumatoid arthritis, and chronic inflammatory bowel diseases. ${ }^{1}$ High concentrations of immune complexes are also found in many forms of disseminated malignancy ${ }^{2}$ where it is thought that they may have an enhancing effect on tumour growth, by preventing the host from mounting an effective immune response to his own tumour. ${ }^{3}$

Paradoxically, immune complexes are also found, in low concentrations, in the sera of apparently healthy people, particularly after food ${ }^{4}$ they have also been described in normal pregnancy, ${ }^{5}$ and in pre-eclampsia. ${ }^{6}$ The finding of immune complexes in so many different diseases as well as in normal biological states raises the question whether they do indeed play a crucial role in pathological processes.

\section{Evidence for a damaging role of immune complexes}

Much of the evidence comes from animal studies, in particular those in which chronic nephritis is induced by repeated antigen administration. ${ }^{7}$ The most widely quoted experimental model of immune complex injury is serum sickness, in which the animal develops nephritis and vasculitis due to deposition of immune complexes 8-10 days after the injection of antigen. When the antigen is still in $\vec{A}$ excess of antibody within the circulation, the small 을 immune complexes formed remain in solution but can become trapped in vessel walls at sites of $z$ turbulence or at capillary membranes where filtration occurs. Tissue damage at these sites results from the biological effects of complexes which activate the complement system, resulting in immune adherence polymorph chemotaxis, release of lysosomal prog teolytic enzymes and kinins, and platelet aggregation The latter causes release of vasoactive amines ${ }^{8}$ which increase vascular permeability and so further localise complexes to the site of the injury.

If sections of the kidneys are examined at the height of injury, the glomeruli show evidence of nephritis, with endothelial cell swelling and lifting of the underlying basement membrane. Immunofluorescence shows immunoglobulins of different classes and various complement components deposited in an irregular granular manner along the capillary basement membrane. ${ }^{9}$ A similar distribution of electron-dense deposits may be shown by electron microscopy. 10 Despite the similarities between animal and human nephritis, there is still controversy about the role of circulating soluble immune complexes in man; indeed in membranous nephropathy and acute poststreptococcal nephritis it may be difficult to demonstrate immune complexes in the circulation, yet the renal biopsies show the classical granular deposition of immunoglobulins and complement components. In animals it is possible to induce local formation of immune complexes within glomeruli by the intravenous injection of bacterial lipopolysaccharide. ${ }^{11} \mathrm{It}$ is certainly possible that in many forms of glomerulonephritis an extrinsic antigen provokes the initial injury, possibly releasing : hidden self-antigens which elicit an immune response resulting in the formation of immune complexes at 
the site of damage. Local formation of complexes or deposition of circulating immune complexes are not mutually exclusive mechanisms of tissue damage, but it must be emphasised that the mere demonstration of soluble immune complexes in the circulation does not necessarily mean that they are directly responsible for the disease.

Host factors contributing to variation in susceptibility to immune complex disease

In human poststreptococcal glomerulonephritis, as in serum sickness, the majority of individuals recover from the disease rapidly and completely. Only a very small minority develop chronic glomerulonephritis with ensuing renal failure. Such variation in immune response to an antigen may be demonstrated in experimental nephritis in rabbits where only those animals producing non-precipitating (poor quality) antibody develop chronic disease; those producing precipitating antibody get acute nephritis and recover. ${ }^{12}$ Oldstone and Dixon ${ }^{13}$ demonstrated that only certain strains of mice were susceptible to chronic nephritis when infected with lymphocytic choriomeningitis virus in the neonatal period. In response to antigen injected in saline, the strains of mice susceptible to chronic nephritis produced lower-affinity antibody-that is, with weaker antigen-antibody binding than the nephritisresistant animals, ${ }^{14}$ suggesting that susceptibility was genetically determined. Low affinity antibody is poor at antigen elimination ${ }^{15}$ and is one example of a defective rather than an overactive immune system failing to eliminate antigen and so predisposing to chronic immune complex disease. There are many examples in man of immune complex disease with underlying primary immune deficiency-for example, the higher incidence of juvenile chronic polyarthritis in children with selective IgA deficiency, ${ }^{16}$ the arthritis complicating hypogammaglobulinaemia, ${ }^{17}$ and the increased incidence of diseases such as systemic lupus erythematosus in people with inherited deficiencies of the complement system, in particular homozygous $\mathrm{C} 2$ deficiency. ${ }^{18}$

The genetic differences in susceptibility to immune complex disease in animals is antigen non-specific. It is likely that this is true also for man since a common antigen such as hepatitis B can occur in the healthy carrier state, yet has been incriminated in such different diseases as chronic active hepatitis, ${ }^{19}$ membranous nephropathy, ${ }^{20}$ and polyarteritis nodosa. ${ }^{21}$

\section{Factors affecting immune-complex formation, deposition and elimination}

There are many variables involved in the formation of immune complexes. There is the wide variety of antigens available, mostly extrinsic such as products of viruses, bacteria, parasites, moulds and ingested food antigens, but some are intrinsic such as DNA, RNA, immunoglobulins and other proteins. The portal of entry for the antigen may be important in the type of immune response elicited; entry via the gastrointestinal tract may be more likely to producean IgA antibody response than entry by respiratory or parenteral routes. If the antigen is a virus or a parasite, its mode of replication within the host and the subsequent release of reproductive antigenic material may be important in producing different types of immune complexes.

The different immunoglobulin classes and subclasses of antibodies impart different biological properties to the immune complexes. Theoretically, immune complexes may be produced by all the immunoglobulin classes, and some evidence has been provided for complexes involving IgM, IgG, $\operatorname{IgA}$ and also $\operatorname{IgE}{ }^{22-24}$ The complement-binding characteristic of the immune complex is determined by the class of immunoglobulin involved, and the size of the complex depends on factors such as the antibody:antigen ratio, strength of antibody binding and whether secondary interaction has occurred with rheumatoid factors or immunoconglutinin, a naturally occurring human IgM antibody to activated C3bi. Another factor is the action of complement in solubilising membranebound immune complexes. ${ }^{25}$

Thus immune complexes vary not only in the antigen but also in the immunoglobulin class and subclass, in size, in complement-binding capacity and in the antigen:antibody ratio (Fig. 1). All these features may be important in the localisation of complexes in one organ rather than another, and in the different syndromes and diseases which result.

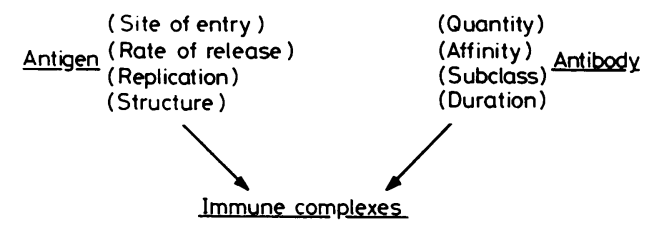

Varying in antigen, antibody class and subclass, size, complement binding capacity as well as $\mathrm{Ag} / \mathrm{Ab}$ ratio

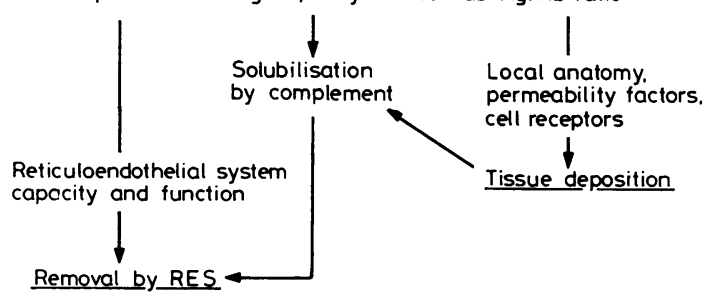

Fig. 1 Factors affecting immune complex formation and elimination. 
The factors underlying the deposition of immune complexes in tissues are not fully understood. They must include the rate of formation, the rate of clearance and the efficiency of elimination by the reticuloendothelial system, as well as the rate of blood flow through the organ. Furthermore the size of the complex was shown to be important in renal localisation in animals by Germuth and Rodrigues, ${ }^{26}$ who demonstrated that medium sized complexes of bovine serum albumin (BSA)/anti-BSA were nephrotoxic in rabbits whereas larger ones were not. Similarly, when well-defined dinitrophenol (DNP)/ anti-DNP immune complexes were injected into rats, complexes of intermediate size (greater than 19S) became localised in the mesangium of the renal glomerulus whereas very large complexes became localised transiently as microemboli in the lumen of capillaries in the lung, skin, and heart. ${ }^{27}$

Elimination of immune complexes is dependent on the functional capacity of the reticuloendothelial system which may easily become overloaded. Blockage of the macrophage system in animals by injection of carbon particles facilitated glomerular deposition of preformed complexes injected subsequently. ${ }^{28}$ Localisation in this instance was in subendothelial areas whereas without carbon blockade the immune complexes were deposited only in the mesangium, ${ }^{29} 30$ altnough at higher dosage some capillary localisation does occur. ${ }^{27} 3132$ In contrast, in human disease and in animals with chronic nephritis produced by prolonged antigen administration, complexes may be found within the glomerular basement membrane. ${ }^{32}$ Mannik $(1979)^{33}$ has suggested that complexes are carried across the basement membrane from endothelium to epithelial cell to mesangial cell, and elimination occurs at the latter site. The alternative view is that localisation in the basement membrane or subepithelially is due to local formation and not due to deposition of circulating complexes. ${ }^{34} \mathrm{C} 3 \mathrm{~b}$ receptors have been found on the epitnelial cell surface in the glomeruli, ${ }^{35}$ and these receptors are blocked in the glomerular diseases which are thought to be mediated by immune complexes. ${ }^{36}$ It is an attractive suggestion that immune complexes become localised in an organ such as the kidney because of specific receptors, but the site of these receptors does not coincide with the distribution of complexes found by electron microscopy in human disease.

The finding of various complement components in tissues by immunofluorescence indicates the importance of ccmplement activation in the mechanism of injury. Complement also has a clearance function since membrane-bound immune complexes may be solubilised by the insertion of $\mathrm{C} 3 \mathrm{~b}$ and possibly $\mathrm{C} 4 \mathrm{~b}$ into the antigen-antibody lattice, so splitting large complexes into smaller ones. ${ }^{25}$ Complementsolubilised immune complexes have a low binding affinity for platelet and neutrophil membranes, ${ }^{37} 38$ and hence may be less able to mediate the release of vasoactive amines and lysozomal enzymes from these cells.

It is thought that a local increase in vascular permeability facilitates immune complex deposition; histamine injected into an animal intravenously at the time of immune complex injection localises complexes to lung capillaries. ${ }^{39}$ Platelets are a rich source of histamine and other vascular permeability factors. In acute serum sickness in rabbits, basophil depletion and degranulation occur at the time of glomerular injury and it has been suggested that IgE antibodies are produced and bind to mast cells causing degranulation in the presence of antigen and release of platelet-activating factor which causes platelet clumping with subsequent release of vasoactive amines. ${ }^{40}$ Human platelets may be aggregated by platelet-activating factor and it is certainly possible that this mechanism is involved in immune complex nephritis in man.

Macrophages and polymorphs have receptors for IgG Fc and $\mathrm{C} 3 \mathrm{~b}$, so clearance of IgG complexes by the former and IgM complexes by the latter (if complement is activated) can be envisaged. Recentlyo a transport system has been proposed for the passage of dimeric $\operatorname{IgA}$ and $\operatorname{IgA}$ complexes through the hepatocyte into the biliary system, which recognises the secretory piece linking the $\mathrm{IgA}$ molecules. ${ }^{41}$ Since IgA immune complexes appear to constitute a normal physiological clearance mechanism for food antigens entering across the gut mucosa ( $R$ Paganelli and RJ Levinsky unpublished data, 1981), it is possible that in diseases where deposition of $\lg \mathrm{A}$ immune complexes in the kidney are a predominant feature, the defect lies in the liver transport mechanisms.

\section{Antigens involved in renal immune-complex diseases} Table 1 gives some of the antigens which have been implicated in human immune complex nephritis. In most cases of nephritis in man, however, no antigen is identified either in the circulation or in the kidney biopsy material or indeed even suspected. Antibodies against extrinsic antigens may cross-react with self-protein so that the continuing presence of the antigen is no longer necessary for a disease process to continue, since the antibody formed then reacts against the host tissue. Systemic lupus erythematosus (SLE) may well be such an example where antibody produced against viral DNA cross-reacts with host DNA. Such a mechanism could also lead to local formation of immune complexes if further antigens 
Table 1 Antigens involved in renal immune complex diseases

\begin{tabular}{ll}
\hline Extrinsic & Intrinsic \\
\hline Bacteria & DNA \\
Streptococcus spp & Tumour antigens \\
Staphylococus spp & Carcinoembryonic antigen \\
Mycobacterium leprae & Thyroglobulin \\
Treporiema pallidum & \\
Viruses & \\
Hepatitis B & \\
Epstein-Barr & \\
Varicella & \\
Mumps & \\
Rickettsia spp & \\
Parasites & \\
Malaria & \\
Schistosoma & \\
Drugs (examples) & \\
Penicillin & \\
Penicillamine & \\
Gold & \\
\hline
\end{tabular}

are uncovered at the site of a damaged basement membrane.

A further intriguing possibility is that many of the immune complexes are non-specific, induced by an antigen which causes polyclonal activation of B lymphocytes with the result that rheumatoid factors and other autoantibodies such as those to DNA are formed. Such a mechanism occurs in mice injected with bacterial lipopolysaccharide, ${ }^{42}$ or infected experimentally with trypanosomiasis. ${ }^{43}$ Furthermore, Roberts and Lewis ${ }^{44}$ demonstrated both DNA and its antibodies in cryoprecipitates in patients with SLE and also with other forms of nephritis or intercurrent bacterial infections. A hypothetical model for the non-specific induction of immune complexes is illustrated in Fig. 2. Immune deficiency is proposed as the underlying trigger which allows persistence of antigens within the circulation and tissues, leading to host cell disruption and autoantibody formation. The system becomes selfgenerating when there is a failure of control mechanisms such as a lack of suppressor cell control of polyclonal B cell activation in this model.

\section{Principles of immune complex detection}

All the techniques for detecting immune complexes are based upon either their physicochemical properties which are mainly due to size, or their biological properties which depend upon their binding to other humoral proteins or to specific cell receptors (Table 2).

With the exception of the electron microscope, by which it is occasionally possible to identify the specific antigen, all the other techniques are antigen non-specific. The antiantibody method, which

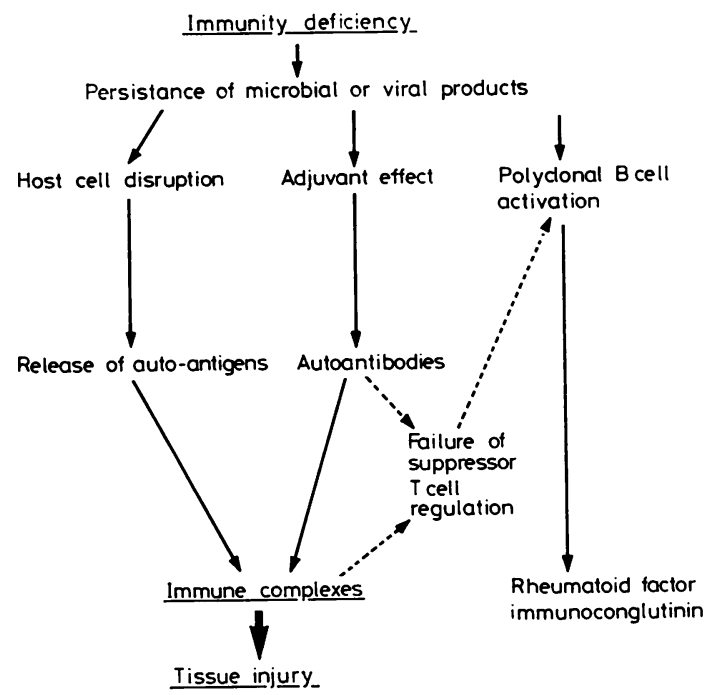

Fig. 2 Non-specific induction of immune complexes.

Table 2 Principles of methods of immune complex detection

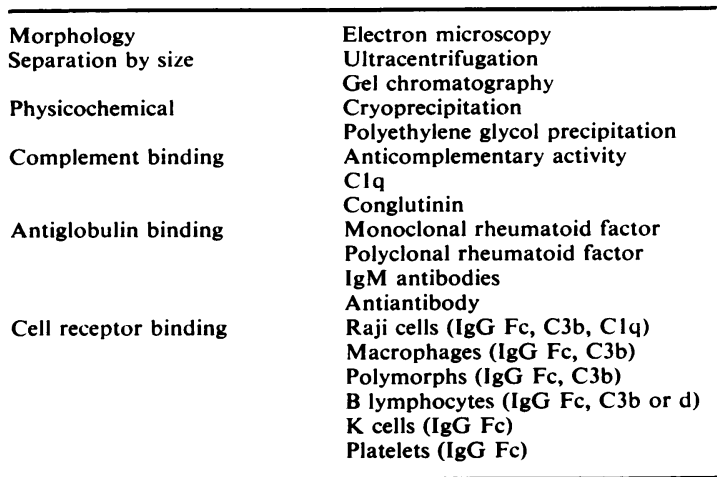

recognises the conformational change occurring at the antigen-binding site when the antibody combines with antigen, is the only one of these antigen nonspecific techniques capable of distinguishing aggregated IgG from an antigen-antibody complex. Although the assays have usually been shown to detect preformed immune complexes, false-positives due to aggregated immunoglobulins may easily be obtained.

Separation of immune complexes by ultracentrifugation or gel chromatography is relatively crude and requires further analysis of the macromolecular fraction by immunochemical methods. The simplest technique for detecting immune complexes is by cryoprecipitation. Cryoprecipitates have been described in many diseases, and in certain instances 
have been shown to contain antigen, antibody and activated complement components. ${ }^{45}$

Polyethylene glycol (PEG), in common with other uncharged water-soluble polymers such as dextran or polyvinyl pyrolidone, will precipitate proteins without denaturation according to their molecular weight. ${ }^{46}$ The reaction is not specific and the amount of uncomplexed monomeric immunoglobulin coprecipitated depends upon the concentration of PEG ( $2-3 \%$ is optimal for immune complex precipitation).

The techniques based on complement interaction depend either upon activation of additional complement (anticomplementary method) upon binding to $\mathrm{Clq}$, the recognition protein of the classical complement pathway which binds to the Fc region of IgM, $\mathrm{IgG}_{1}, \mathrm{IgG}_{2}$ and of $\mathrm{IgG}_{3}$, or binding by bovine conglutinin to the activated $\mathrm{C} 3(\mathrm{C} 3 \mathrm{bi})$ within the immune complex (conglutinin is a bovine protein of nonimmunological origin which binds $\mathrm{C} 3 \mathrm{bi}$ ). Whereas the first two methods require that the immune complex activates the classical pathway, the reaction with bovine conglutinin can follow complement activation by either the classical or the alternative pathway. It is possible that conglutinin only binds to those complexes solubilised by complement and released back into the circulation where they no longer play any pathological role.

Antiglobulin binding (whether by monoclonal rheumatoid factors, polyclonal rheumatoid factors or IgM antibodies to human immunoglobulins) depends upon the multivalency of IgM antibodies in which each of the binding sites in the Fab portion of the molecule is of low affinity, but stable binding to aggregated or complexed immunoglobulins occurs because of multipoint attachment. ${ }^{47} 48$ Antiantibody is also an IgM antibody, but differs from rheumatoid factor in recognising the antigen-binding site at the Fab portion of the immunoglobulin molecule. ${ }^{49}$

Immune complex detection by cell receptor binding differs according to the specific receptor involved (Table 2). Where IgG Fc receptors are used, monomeric $\mathrm{IgG}$ is distinguished from $\mathrm{IgG}$ in complexed form by the stronger binding of the latter, owing to their attachment to the cells at multiple sites. Cells with complement receptors only react with activated complement components, either $\mathrm{C} 3 \mathrm{~b}$ or $\mathrm{C} 3 \mathrm{~d}$.

None of the techniques is ideal; all give falsepositives and false-negatives and none of them is capable of characterising the immune complex in terms of its constituents. However, when several different tests with different biological specificities are used to analyse sera, a great deal of information can be obtained.

Heterogeneity of immune complexes in renal disease The WHOcollaborativestudy of 18 different methods for immune complex detection produced widely discrepant results for the same sera in different diseases. ${ }^{50}$ Table 3 gives the results of 10 commonly

Table 3 Comparison of 10 different immune complex assays on same SLE sera

\begin{tabular}{|c|c|}
\hline Test & $\begin{array}{l}\text { \% showing } \\
\text { abnormality }\end{array}$ \\
\hline $\mathrm{Clql}^{125} \mathrm{Clq}$ binding in polyethylene glycol ${ }^{62}$ & 58 \\
\hline Clq SP Clq solid phase 6. & 58 \\
\hline Clq DV Clq deviation ${ }^{64}$ & 19) \\
\hline $\begin{array}{l}\text { Clq RI Inhibition of Clq binding to IgG } \\
\text { sepharose }\end{array}$ & 29 \\
\hline KGB SP Conglutinin binding solid phase ${ }^{66}$ & 33 \\
\hline RAJI Raji cell binding ${ }^{67}$ & 86 \\
\hline $\begin{array}{l}\text { MRF-I Inhibition of solid phase monoclonal } \\
\text { rheumatoid factor binding to }{ }^{125} \text { [-aggregated } \\
1 \mathrm{gG}^{6 \times}\end{array}$ & 29 \\
\hline Plat Agg Platelet aggregation ${ }^{69}$ & 65 \\
\hline $\mathrm{K}$ cell Inhibition of $\mathrm{K}$ cell cytotoxicity ${ }^{70}$ & 68 \\
\hline $\begin{array}{l}\text { MRFR I Inhibition of soluble monoclonal } \\
\text { rheumatoid factor binding to IgG sepharose }\end{array}$ & 4 \\
\hline
\end{tabular}

Data adapted from WHO collaborative study.

used assays applied to the same SLE sera; it is readily apparent that in this disease some assays give a higher percentage of positives than others with the Raji cell assay ranking highest, due in part to false-positive reactions with antilymphocyte antio bodies. However by understanding the specificities a the different assays and applying several wit different probes to the same serum, some degree of characterisation can be achieved. Since immune complexes are clearly heterogeneous and only some are of pathological significance, it is important to apply this type of finger-printing exercise in order to assess whether the immune complexes play any role in a particular disease. Table 4 indicates how the size

Table 4 Size of $\mathrm{IgG}$ immune complexes in relation to clinical signs in SLE

\begin{tabular}{lllll}
\hline Signs & No studied & \multicolumn{2}{l}{$\begin{array}{l}\text { Size of complex (approximate molecular } \\
\text { weight in daltons) }\end{array}$} \\
\cline { 3 - 5 } & & $\begin{array}{l}\text { Small } \\
312000\end{array}$ & $\begin{array}{l}\text { Medium } \\
1 \cdot 0-1 \cdot 5 \times 10^{6}\end{array}$ & $\begin{array}{l}\text { Large } \\
2 \cdot 5-4 \cdot 0 \times 10^{6}\end{array}$ \\
\hline $\begin{array}{l}\text { Renal only } \\
\begin{array}{c}\text { Renal plus } \\
\text { extrarenal }\end{array}\end{array}$ & 1 & 1 & 1 & 1 \\
$\begin{array}{c}\text { Extrarenal } \\
\text { only }\end{array}$ & 5 & 7 & 7 & 7 \\
\hline
\end{tabular}

of IgG-and C1q-binding immune complexes may be important for renal damage in lupus nephritis. Those of medium size are associated with the renal lesions, whereas extravascular lesions are associated with much larger immune complexes. These observations, confirmed by others, ${ }^{51}$ extend those of Germuth et al..$^{52}$ who showed that in the chronic nephritis 
induced in animals, nephrotoxicity was also related to the medium-sized immune complexes. Yet it is apparent from observations on the size of complexes in Behçet's syndrome, ${ }^{53}$ in which renal lesions are rare although medium-sized IgG complexes do occur, that immune complex size alone is not the only factor governing renal localisation. It is likely that specific receptors are involved, but the immune deposits seen on the endothelial surface of the GBM cannot be explained by our current views on localisation, as $\mathrm{C} 3 \mathrm{~b}$ receptors have not been demonstrated on the endothelial surface.

The finding of IgG complexes which do not bind $\mathrm{Clq}$ in the steroid-responsive nephrotic syndrome ${ }^{54}$ suggests involvement of one of the IgG subclasses which is poor at activating complement $\left(\mathrm{IgG}_{4}\right.$ and $\mathrm{IgG}_{2}$ ). These complexes apparently are not deposited in the kidney and it is not known whether they are in any way responsible for the heavy proteinuria. The concept of Lagrue et al.,55 who suggested that proteinuria was due to a lymphokine causing increased vascular permeability, is so far unsubstantiated, but this type of interrelationship between immune complexes and $\mathrm{T}$ cell immune responses is still unexplored in human diseases. The particular type of immune complex found in the steroidresponsive nephrotic syndrome suggests that complement binding may be a prerequisite for renal localisation. The complexes found in this disease are large $\left(2.5 \times 10^{6}\right.$ daltons), yet no evidence of deposition can be demonstrated by immunofluorescent techniques. In addition, the findings in Henoch-Schönlein purpura (HSP), where the nephritis is associated with IgG complexes of similar size to those of the steroid-responsive nephrotic syndrome, ${ }^{56}$ suggest that additional factors operate in causing renal localisation and damage. In HSP, although the complexes do not bind C1q, there is evidence of complement activation since $\mathbf{C} 3$, properdin, IgG, and IgA may be demonstrated by immunofluorescent staining of renal biopsy material. Here the evidence suggests that, if complement activation is necessary for the localisation of complexes in the kidneys in HSP, it is by the alternative pathway.

IgA immune complexes have been demonstrated in several diseases. Their role is unclear but it is possible that their formation is the normal response to an antigen entering via a mucosal surface and that they only become deposited in tissues as "bystanders" when their clearance is impaired. The elegant transport system in which the secretory piece on the hepatocyte binds to dimeric or complexed $\operatorname{IgA}$ (only demonstrated in the rat so $\mathrm{far}^{41}$ ) and transports the secretory IgA into the bile with antigen degradation occurring intracellularly, provides a normal physiological clearance mechanism for such complexes.
The normal response to the entry of food antigen into the circulation after eating is the formation of IgA immune complexes which are presumably cleared by this hepatic route. That the type of immune complex is important for the development of disease symptoms is supported by the fact that the response differs in subjects allergic to food where the complexes after food challenge contain IgG and IgE, are C1q-binding and are associated with symptoms of skin itching and wheezing. 57

In Behçet's syndrome, in HSP and in idiopathic recurrent haematuria of childhood, diseases all associated with high concentrations of $\operatorname{IgA}$ complexes, the more damaging elements of these diseases only occur either when there is a switch to IgG- and Clq-binding complexes, as in Behçet's syndrome, or when IgA and IgG complexes occur together, as in HSP, nephritis, and recurrent haematuria. ${ }^{58}$ It is possible that in these diseases the IgA complexes inhibit the clearance of IgG immune complexes by polymorphs. ${ }^{59}$ If this is so, there is no reason to believe that the same antigen is involved in these two types of immune complexes.

Table 5 illustrates certain aspects of this "fingerprinting" exercise for renal diseases in which immune complexes may play a role.

Table 5 Different types of immune complexes found in certain forms of nephritis ${ }^{58}$

\begin{tabular}{|c|c|c|c|}
\hline & $\operatorname{IgG}$ & $\operatorname{Ig} A$ & CIq binding \\
\hline SLE nephritis & + & + & + \\
\hline Acute nephritis & + & - & \pm \\
\hline $\begin{array}{l}\text { Steroid-responsive nephrotic syndrome } \\
\text { in relapse } \\
\text { Henoch-Schönlein purpura without }\end{array}$ & + & \pm & - \\
\hline $\begin{array}{l}\text { nephritis } \\
\text { Henoch-Schönlein purpura with }\end{array}$ & - & + & - \\
\hline nephritis & + & + & - \\
\hline IgA nephropathy in remission & - & + & - \\
\hline $\begin{array}{l}\text { IgA nephropathy during haematuria } \\
\text { Subacute bacterial endocarditis }\end{array}$ & + & + & - \\
\hline nephritis & + & - & + \\
\hline
\end{tabular}

+ Denotes raised concentrations in most patients.

\pm Denotes raised concentrations in a few patients only.

- Denotes concentrations not raised.

\section{Is measurement of immune complexes clinically}

useful?

It is important to distinguish between a test which may be of diagnostic value and one which is useful for monitoring the clinical course of patients during different treatments.

At present, the detection of soluble immune complexes in serum does not provide any diagnostic help. It is possible however that in the future, when immune complex characterisation is more precise, the finding of a particular type of immune complex in a disease will provide diagnostic distinction. 
The question of whether measurement of immune complex concentrations is clinically useful for monitoring treatment of patients is also difficult to answer. Immune complexes, by their very nature, are difficult to quantify. They represent a dynamic equilibrium of antigens and antibodies, with continual immune complex formation and elimination; in addition the secondary binding of other proteins such as complement components, rheumatoid factors and immunoconglutinin, adds to the problem of quantification. Furthermore, we have little idea how various forms of treatment alter this immune complex equilibrium in terms of individual constituents, or how their formation and elimination is affected. Nonetheless, immune complex concentrations, measured semiquantitatively, may correlate well with disease activity in some diseases
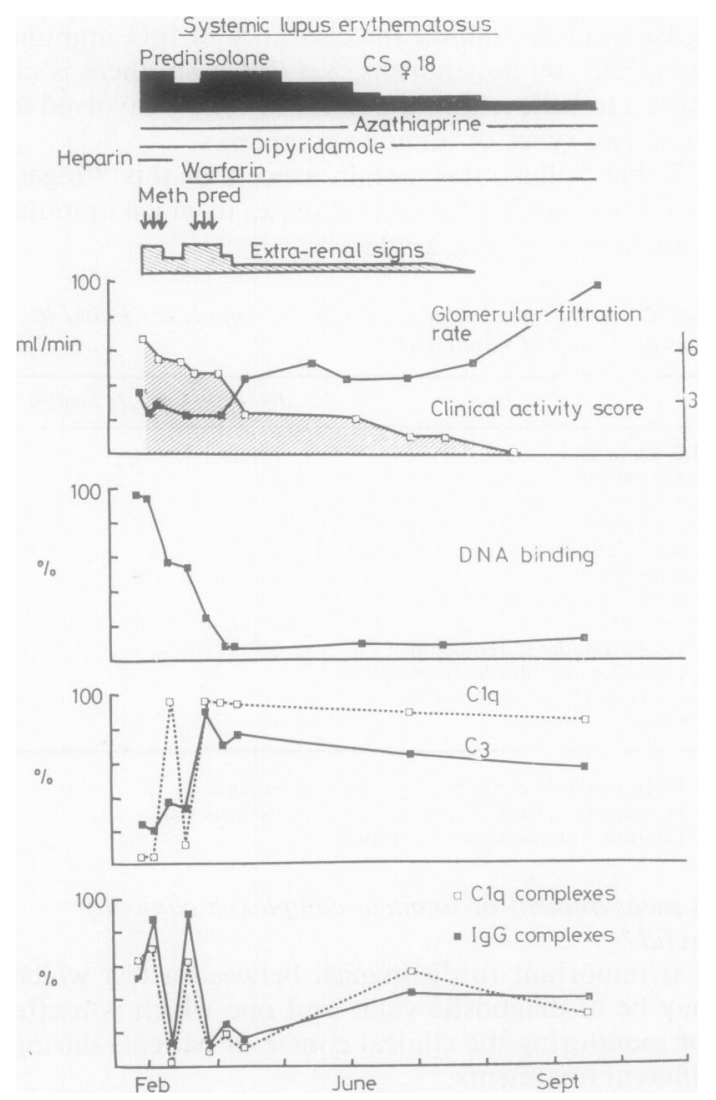

Fig. 3 Clirical course and plasma concentrations of immune complexes and complement components in an 18-year-old woman with a post-partum SLE crisis. The concentrations of IgG-containing and Clq-binding immune complexes correlated very well with her clinical condition. (Reprinted with permission of the editor of the Lancet.) such as lupus nephritis (Fig. 3), though in others, such as steroid-responsive nephrotic syndrome and HSP nephritis, no such correlation is obtained (Fig. 4).
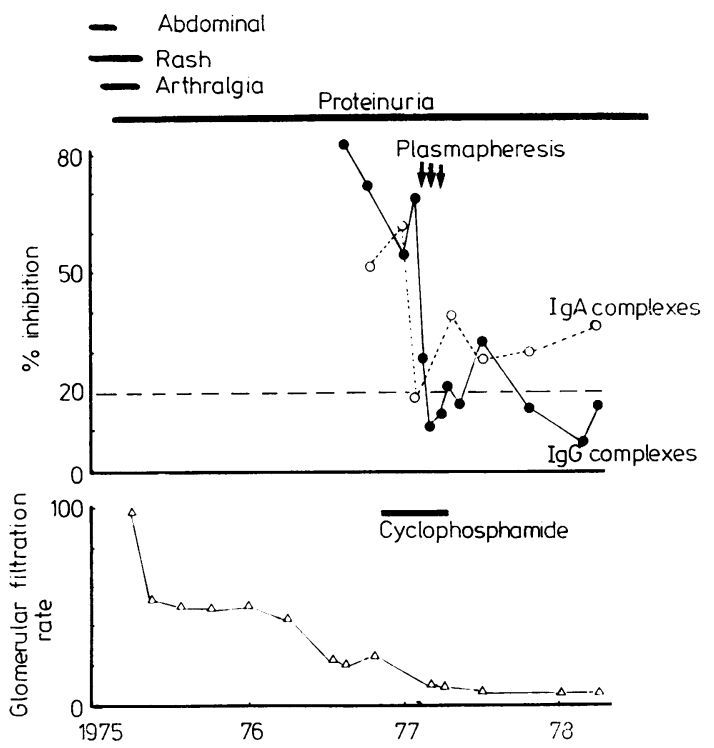

Fig. 4 Clinical course in a boy with Henoch-

Schönlein purpura and nephritis who eventually required haemodialysis for his end-stage renal failure. ${ }^{56}$ There was no correlation of his progressive renal deterioration with concentrations of circulating IgG or IgA complexes. (Reprinted with permission of the Editor of the Lancet.)

\section{Conclusions}

The differences shown in the immune complexes in the different renal diseases illustrate how a single technique is not of great use for their detection. Characterisation in terms of size, immunoglobulin class and complement components as well as the antigen are all necessary in order to assess their role in disease. It must also be emphasised that their mere presence in the circulation does not necessarily mean that they have a causal role. It has become apparent that not only are immune complexes important for normal clearance mechanisms, but they play a vital part in modulating immune responses; indeed some of those detected may be idiotype/anti-idiotype complexes. ${ }^{60}$ There is also much evidence to indicate how they modulate $T$ cell and B cell function. ${ }^{61}$ Table 6 lists some of the known biological effects of immune complexes. It is only by careful characterisation that we may be able, in time, to distinguish between those which cause 
Table 6 Effects of immune complexes

Localised inflammatory foci-nephritis

Systemic tissue lesions-SLE

Impairment of effector mechanisms-polymorph, eosinophil, $\mathrm{K}$ cell

Modulation of immune response-help, suppression, anti-idiotype network

disease and those which are essential for immune regulation.

I thank the National Fund for Research into Crippling Diseases and the Nuffield Foundation for generous grant support.

\section{References}

1 WHO Scientific Group. The role of immune complexes in diseases. WHO Tech Rep Ser 1977:606.

2 Theofilopoulos AN Andrews BS, Urist BM, Morton DL, Dixon FJ. The nature of immune complexes in human cancer sera. J Immunol 1977;119:657.

${ }^{3}$ Hellström KE, Hellström I. Lymphocyte mediated cytotoxicity and blocking serum activity to tumour antigens. Adv Immunol 1974;18:209.

+ Paganelli R, Levinsky RJ, Brostoff J, Wraith DG. Immune complexes containing food proteins in normal and atopic subjects after oral challenge and effect of sodium cromoglycate on antigen absorption. Lancet 1979 ; $1: 1270$.

5 Masson PL, Delire M, Cambiaso CC. Circulating immune complexes in normal human pregnancy. Nature 1977; 266:542.

6 Stirrat GM, Redman CWG, Levinsky RJ. Circulating immune complexes in pre-eclampsia. $\mathrm{Br}$ Med J 1978; : 1450.

'Unanue ER, Dixon FJ. Experimental glomerulonephritis: immunological events and pathogenetic mechanisms. Adv Immunol 1967;6:1.

${ }^{8}$ Henson PM, Spiegelberg HL. Release of serotonin from human platelets induced by aggregated immunoglobulins of different classes and subclasses. J Clin Invest $1973 ; 52: 1282$.

${ }^{9}$ Cochrane CG, Dixon FJ. In: Miescher PA, MullerEberhard HJ, eds. Textbook of immunopathology. Vol 1. New York: Grune and Stratton, 1968:94.

${ }^{10}$ Fish AJ, Michael AF, Vernier RL, Good RA. Acute serum sickness nephritis in the rabbit. Am J Pathol 1966; 49:997.

${ }^{11}$ Izui S, Lambert PH, Miescher PA. In vitro demonstration of a particular affinity of glomerular basement membrane and collagen for DNA. A possible basis for a local formation of DNA/anti-DNA complexes in SLE. $J$ Exp Med 1976;144:428.

12 Pincus $T$, Haberkern $R$, Christian CL. Experimental chronic glomerulitis. J Exp Med 1968;127:819.

13 Oldstone MBA, Dixon FJ. Pathogenesis of chronic disease associated with persistent lymphocytic choriomeningitis viral infection. I. Relationship of antibody production to disease in neonatally infected mice. $J$ Exp Med 1969;129:483.

"Soothill JF, Steward MW. The immunopathological significance of the heterogeneity of antibody affinity. Clin Exp Immunol 1971;9:193.

${ }^{15}$ Alpers JH, Steward MW, Soothill JF. Differences in immune elimination in inbred mice. The role of low affinity antibody. Clin Exp Immunol 1972;12:121.

${ }^{16}$ Cassidy JT, Burt A, Petty R, Sullivan D. Selective IgA deficiency in connective tissue diseases. $N$ Engl $\mathrm{J} \mathrm{Med}$ $1969 ; 280: 275$.

${ }^{17}$ Lawrence JS. Rheumatic disease in hypogammaglobulinaemia patients and their relatives. In: Hypogammaglobulinaemia in the United Kingdom. MRC Special Report Series. No 310. London: HMSO, 1971: 35-44.

18 Day NK, Geiger H, McLean R, Michael A, Good RA. C2 deficiency; recognition of systemic lupus erythematosus. J Clin Invest $1973 ; 52: 1601$.

19 Almeida JD, Waterson AP. Immune complexes in hepatitis. Lancet 1969 ;ii:983.

${ }^{20}$ Combes B, Stastny P, Shoney J, et al. Glomerulonephritis with deposition of Australia antigen-antibody complexes in glomerular basement membrane. Lancet 1971 ;ii :234.

21 Gocke DJ, Hsu K, Morgan C. Association between polyarteritis and Australia antigen. Lancet 1970;ii:1149.

${ }^{22}$ Soothill JF. Detection and measurement of circulating soluble antigen-antibody complexes and anti-DNA antibodies. Ann Rheum Dis 1977;36, suppl 64.

${ }^{23}$ Levinsky RJ, Soothill JF. The heterogeneity of immune complexes in disease. In: Peeters $\mathrm{H}$, ed. Proteins and related subjects. Vol 26. Protides of the Biological Fluids 26 Colloquium. Pergamon Press, 1979:243.

${ }^{24}$ Brostoff J, Johns P, Stanworth DS. Complexed IgE in atopy. Lancet 1977 ;ii:741.

${ }^{25}$ Miller GW, Nussenzweig V. A new complement function: solubilization of antigen-antibody aggregates. Proc Natl Acad Sci USA 1975;72:418.

${ }^{26}$ Germuth FG, Rodrigues A. Immunopathology of the renal glomerulus. Boston: Little, Brown \& Co, 1973.

${ }^{27}$ Kijlstra A, Knutson DW, V d Lelij A, Van Es LA. Characteristics of soluble immune complexes prepared from oligovalent DNA conjugates and anti-DNA antibodies. J Immunol Methods 1977;17:263.

${ }^{28}$ Ford PM. The effect of manipulation of reticuloendothelial system activity on glomerular deposition of aggregated protein and immune complexes in two different strains of mice. Br J Exp Pathol 1975;56:523.

29 McCluskey RT, Benacerraf B, Potter JL, Miller F. The pathologic effects of intravenously administered soluble antigen-antibody complexes. I. Passive serum sickness in mice. J Exp Med 1960;111:181.

${ }^{30}$ Okumura K, Kondo Y, Tada T. Studies on passive serum sickness nephritis induced by preformed antigenantibody complexes in the mouse. Lab Invest 1971;24: 383.

${ }^{31}$ Haakenstad AO, Striker GE, Mannik M. The glomerular deposition of soluble immune complexes prepared with reduced and alkylated antibodies and with intact antibodies in mice. Lab Invest 1976;35:293.

${ }^{32}$ Andres GA, Seegal BC, Hsu KC, Rothenberg MS, Chapeau ML. Electron microscopic studies of experimental nephritis with ferritin-conjugated antibody. Localisation of antigen-antibody complexes in rabbit glomeruli following repeated injections of bovine serum albumin. J Exp Med 1963;117:691.

${ }^{33}$ Mannik M. Clearance and glomerular deposition of circulating immune complexes. In: Peeters $\mathbf{H}$, ed. Proteins and related subjects. Vol 26. Protides of the Biological Fluids 26th Colloquium. location: Pergamon Press, 1979:265.

${ }^{34}$ Kijlstra A, Daha MR, Van Es LA. Immune complexes in experimental glomerulonephritis. Behring Inst Mitt 1979; $64: 45$

${ }^{35}$ Gelfand MC, Frank MM, Green I. A receptor for the 3rd component of complement in the human renal 
glomerulus. J Exp Med 1975;142:1029.

${ }^{36}$ Moran J, Colasanti G, Amos N, Peters DK. C3b receptors in glomerular disease. Clin Exp Immunol 1977;28:212.

${ }^{37}$ Miller GW, Saluk PH, Nussenzweig V. Complement dependent release of immune complexes from the lymphocyte membrane. J Exp Med 1973;138:495.

${ }^{38}$ Miller GW, Nussenzweig V. Complement as a regulator of interactions between immune complexes and cell membranes. J Immunol 1974;113:454.

${ }^{39}$ Cochrane CG, Hawkins D. Studies on circulating immune complexes. III. Factors governing the ability of circulating complexes to localize in blood vessels. $J$ Exp Med 1968; 127:137.

${ }^{10}$ Benveniste J, Egido J, Gutierrez-Millet U. Evidence for the involvement of the IgE basophil system in acute serum sickness. Clin Exp Immunol 1976;26:449.

${ }^{11}$ Peppard J, Orlans E, Payne AWR, Andrew E. The elimination of circulating complexes containing polymeric IgA by excretion in the bile. Immunology 1981;42: 83.

${ }^{12}$ Izui S, Lambert PH, Fournie GJ, Turler H, Miescher PA. Features of SLE in mice injected with bacterial lipopolysaccharide. Identification of circulating DNA and renal localisation of DNA/anti-DNA complexes. $J$ Exp Med 1977;145:1115.

${ }^{13}$ Kobayakama T, Louis J, Izui S, Lambert PH. Autoimmune response to DNA, red blood cells and thymocyte antigens in association with polyclonal antibody synthesis during experimental African trypanosomiasis. J Immunol $1979 ; 122: 296$.

"Roberts JL, Lewis EJ. Identification of antinative DNA antibodies in cryoglobulinaemic states. Am J Med 1978; $65: 437$.

${ }^{15}$ McIntosh RM, Kulvinskas C, Kaufman DB. Cryoglobulins II: the biological and chemical properties of cryoproteins in acute post-streptococcal glomerulonephritis. Int Arch Allergy Appl Immunol 1971;41:700.

${ }^{16}$ Harrington JC, Fenton JW, Pert JH. Polymer-induced precipitation of antigen-antibody complexes: "Perciflex" reactions. Immunochemistry $1971 ; 8: 413$.

${ }^{17}$ Eisenberg R. The specificity and polyvalency of binding of a monoclonal rheumatoid factor. Immunochemistry 1976; $13: 355$.

${ }^{18}$ Dissanayake S, Hay FC, Roitt IM. The binding constants of IgM rheumatoid factors and their univalent fragments for native and aggregated human IgG. Immunology 1977; 32:309.

${ }^{49}$ Milgrom F, Dubiski S, Wozniczko G. Human sera with "anti-antibody". Vox Sang 1956;1:172.

50 Lambert PH, Dixon FJ, Zubler RH, et al. WHO collaborative study for the evaluation of eighteen methods for detecting immune complexes in serum. J Clin Lab Immunol 1978;1:1.

51 Van Aarden L. Immunology of DNA. University of Amsterdam: MD Thesis, 1977:141.

52 Germuth FG, Senterfit LB, Dreesman GR. Immune complex disease V. The nature of the circulating complexes associated with glomerular alteration in the chronic BSA-rabbit system. Johns Hopkins Med J 1972; 130:344.

${ }_{53}$ Levinsky RJ, Paganelli R, Lehner T. Immune complexes and their characterisation in Behcet's syndrome and recurrent oral ulcers. In: Lehner T, Barnes CG, eds. Behcet's syndrome-clinical and immunological features. New York: Academic Press, 1979.

${ }^{54}$ Levinsky RJ, Malleson PN, Barratt TM, Soothill JF.
Circulating immune complexes in steroid-responsive nephrotic syndrome. $N$ Engl J Med 1978;298:126.

${ }^{55}$ Lagrue G, Xheneumont S, Branellec A, et al. A vascular permeability factor elaborated from lymphocytes. Demonstration in patients with nephrotic syndrome. Biomedicine 1975;23:37.

${ }^{56}$ Levinsky RJ, Barratt TM. IgA immune complexes in Henoch-Schönlein purpura. Lancet 1979;ii:100.

57 Brostoff J, Carini C, Wraith DG, Paganelli R, Levinsky RJ. Immune complexes in atopy. In: Pepys J, Edwards AM, eds. The Mast Cell-its role in health and disease. Pitman Medical, 1979:380.

${ }^{58}$ Levinsky RJ. Immune complexes in health and disease. University of London: MD Thesis, 1980.

${ }^{59}$ Wilton JMA. Suppression by IgA of IgG mediated phagocytosis by human polymorphonuclear leucocytes. Clin Exp Immunol 1978;34:423.

${ }^{60}$ Rose LM, Lambert PH. The natural occurrence of circulating idiotype-anti-idiotype complexes during a secondary immune response to phosphorylcholine (abstract). Proc 4th Int Congress Immunology 1980.

61 Theofilopoulos AN. Immune complexes in humoral responses; suppressive and enhancing effects. Immunology Today 1980;1:1.

${ }^{62}$ Zubler RH, Lange G, Lambert PH, Miescher PA. Detection of immune complexes by modified ${ }^{125} \mathrm{I} \mathrm{Clq}$ binding test. Effect of heating on the Clq binding by immune complexes and application of the test to systemic lupus erythematosus. J Immunol 1976;116:232.

${ }^{63}$ Hay FC, Nineham LJ, Roitt IM. Routine assay for the detection of immune complexes of known immunoglobulin class using solid phase C1q. Clin Exp Immunol 1976;24:396.

${ }^{64}$ Sobel AT, Bokisch VA, Muller-Eberhard HJ. Clq deviation test for the detection of immune complexes, aggregates of $\mathrm{IgG}$ and bacterial products in human serum. $J \operatorname{Exp}$ Med 1975;142:139.

${ }^{65}$ Gabriel A, Agnello V. Detection of immune complexes. The use of radio-immunoassays with $\mathrm{Clq}$ and monoclonal rheumatoid factor. J Clin Invest 1977;59:990.

${ }^{66}$ Casali P, Bossus A, Carpentier NA, Lambert PH. Solid phase enzyme immunoassay or radioassay for the detection of immune complexes based on their recognition by conglutinin: conglutinin binding test. Clin Exp Immunol 1977;29:342.

${ }_{67}$ Theofilopoulos AN, Wilson CB, Dixon FJ. The Raji cell radio-immunoassay for detecting immune complexes in human sera. J Clin Invest 1976;57:169.

${ }^{68}$ Luthra HS, MacDuffie FC, Hunder GG, Samayoa EA. Immune complexes in sera and synovial fluids of patients with rheumatoid arthritis. Radioimmunoassay with monoclonal rheumatoid factor. J Clin Invest 1975; $56: 458$.

69 Penttinen K, Makela O, Vaheri A. Soluble antigenantibody complexes and platelet aggregation. Acta Pathol Microbiol Scand 1969;77:309.

${ }^{\circ}$ MacLennan ICM. Competition for receptors for immunoglobulin on cytotoxic lymphocytes. Clin Exp Immunol $1972 ; 10: 275$.

Requests for reprints to: Dr RJ Levinsky, Department of Immunology, Institute of Child Health, 30 Guilford Street, London WC1, England. 